Int. J. Dev. Biol. 50: 589-599 (2006)

doi: $10.1387 / \mathrm{ijdb} .062150 \mathrm{ks}$

Review

\title{
Mesodermal anatomies in cnidarian polyps and medusae
}

\author{
KATJA SEIPEL and VOLKER SCHMID* \\ Institute of Zoology, University of Basel, Biocenter/Pharmacenter, Basel, Switzerland
}

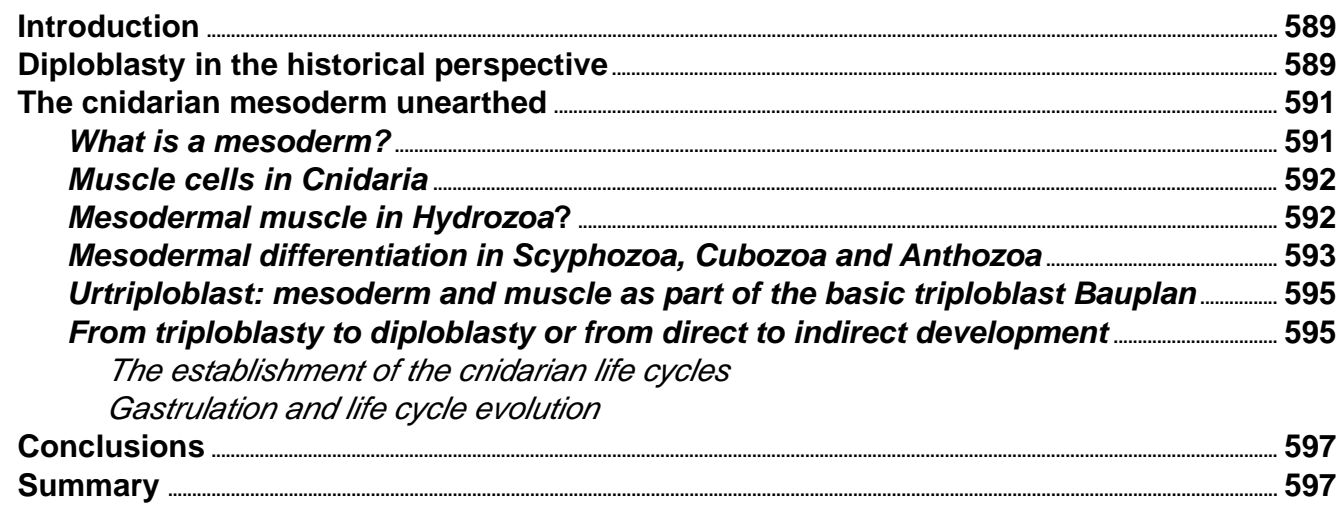

KEY WORDS: Bilateria, Cnidaria, diploblast, mesoderm, medusa, triploblast, Urtriploblast

\section{Introduction}

As sister groups to the Bilateria the Cnidaria and Ctenophora are uniquely suited to trace back the cellular and developmental processes that had been established in the common ancestor and are still prevalent in the extant bilaterians. The Cnidarian phylum consists of four distinct classes: Anthozoa (corals, sea anemones), Cubozoa, Scyphozoa and Hydrozoa, with the latter three classes forming the Medusozoa (jellyfish). While anthozoans live exclusively as polyps, most medusozoan species have life cycles with sessile polyps and pelagic medusa stages. Occasionally either stage can be reduced or completely absent (Tardent, 1978). As of the mid-19th century Cnidaria were regarded as diploblast or two cell-layered animals lacking a mesoderm. The composition of embryonic, larval and adult anatomies based on only two cell layers, ectoderm and endoderm (also entoderm) is well established in the literature. This two-layered tissue organization has produced several hypotheses for the phylogenesis and the evolution of the germ layers (Hyman, 1940; Bouillon, 1993; Technau and Scholz, 2003; Ball et al., 2004; Martindale et al., 2004). Diploblasty in the cnidarian larvae has been interpreted as both ancestral, corroborating Haeckel's blastaea-gastraea theory (Haeckel, 1874) and conserved, with the bilaterian triploblast body plan evolving by simply adding a third germ layer to a diploblast. This view gained much support and basically remained undisputed until recently (reviewed in Seipel and Schmid, 2005).
Here we review additional histological and experimental data corroborating the existence of mesodermal differentiation processes in all cnidarian classes, including the anthozoan and scyphozoan, but not the hydrozoan polyps.

\section{Diploblasty in the historical perspective}

Over 150 years ago Huxley (1849) and Allman (1853) first described diploblast anatomies in jellyfish and polyps, respectively. The morphologies of the cnidarian cell types were analyzed in mazerated tissue from fresh water and marine cnidarian species (Hertwig and Hertwig, 1878; Jickeli, 1882). Allman applied the germ layer terminology to the Cnidaria (Allman, 1853) referring to the two layers as ectoderm and endoderm. Initially this terminology was purely descriptive and of topological character (Baer, 1835; Allman, 1853). Kovalevsky (1871) and Lankester (1877) stressed the developmental homology of the germ layers across invertebrate and vertebrate phyla. The presence of a typical mesoderm derived cell type, the striated muscle, in the medusa, which had been classified as a diploblast, did not raise concerns for two reasons: Striated muscle of the larger medusae had already been described by Eimer (1878), Nasse (1882) and Lendenfeld (1888), but the histological preparations were of minor quality, so that Schneider (1893) concluded that the ap-

Abbreviations used in this paper: ECM, extracellular matrix. *Address correspondence to: Dr. Volker Schmid Institute of Zoology, University of Basel, Biocenter/Pharmacenter, Klingelbergstrasse $50, \mathrm{CH}-4056$ Basel,
Switzerland. Fax: 41-61-267-1627. email: V.Schmid@unibas.ch 
$\mathrm{A}_{1}$

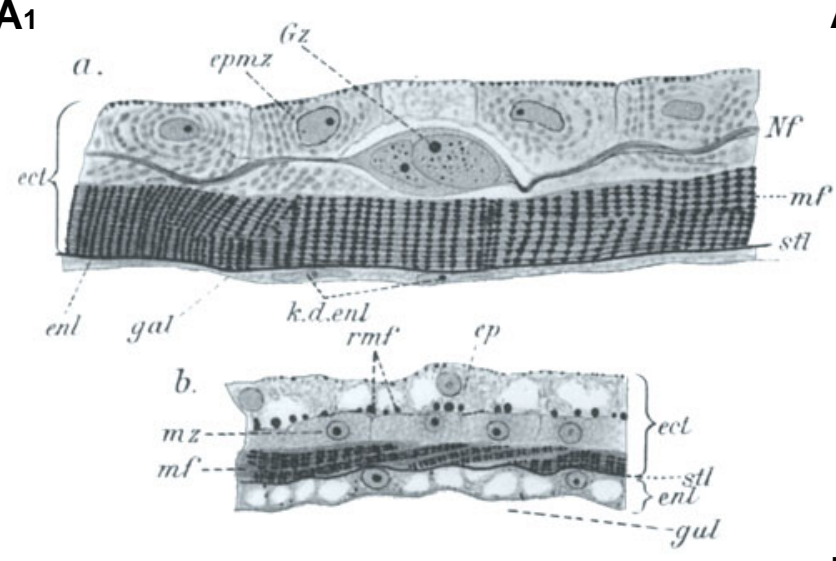

A2

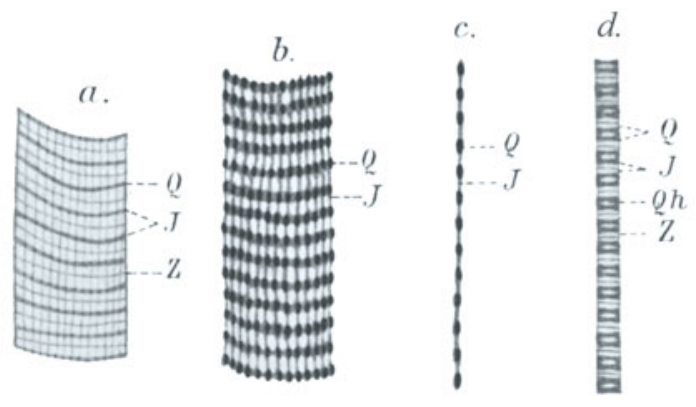

$B_{1}$

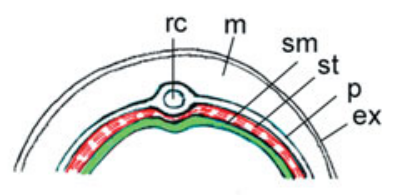

$\mathrm{B}_{2}$

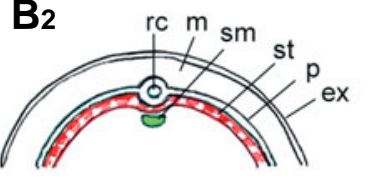

C

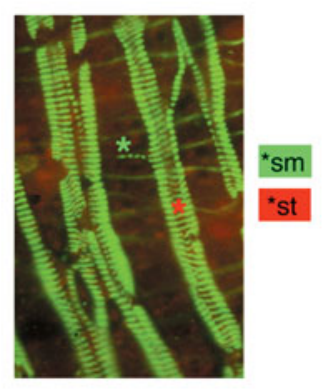

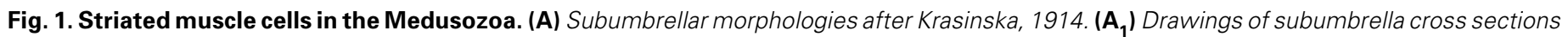
in (a) Carmarina hastate (Trachymedusa, Hydrozoa) and (b) Neoturris pileata (Anthomedusa, Hydrozoa), 1000x; ( $\mathbf{A}_{\mathbf{2}}$ ). Striated myofilaments in the subumbrella of Carmarina hastate (a-c) and Neoturris pileata (d), 2000x. Abbreviations: ect, ectoderm; enl, endoderm lamella; ep, epithelium; epmz, epithelial muscle (myo-epithelial) cell; gal, mesoglea; Gz, ganglion cell with neurofilament (Nf); k.d.enl, nuclei of endodermal lamella; mf, (striated) myofilaments; mz, (striated) muscle cell; rmf, radial (smooth) muscle filaments; stl, mesoglea between muscle and endodermal layer.(B) Distribution of entocodon derived striated (red) and smooth muscle (green) in the medusa bell. Schematic drawings of sagittal (B) and cross sections ( $\mathbf{B}_{\mathbf{1}}$, $\mathbf{B}_{\mathbf{2}}$ ) of the medusa bell in the Leptomedusa Clytia hemisphaerica (B, B1) and the Anthomedusa Podocoryne carnea (B2). In the Leptomedusae (Chapman, 1968) and few Anthomedusae (Hyman, 1940), the striated muscle (red) is completely covered (B, B1) by flagellated smooth muscle epithelia (green), while in the Scyphomedusae and Cubomedusae, the striated muscle is covered by a non-muscled epithelium (Franc, 1993; Chapman, 1999). In many Anthomedusae (Bouillon, 1993) the striated muscle is only partially covered (B2) by flagellated smooth muscle over the radial canals. (C) Phalloidin stained preparation of the muscle systems in the bell of the Leptomedusa Clytia hemisphaerica. The radial smooth muscle runs perpendicular to the striated muscle. The tissue has been spread by squeezing for better visibility of the arrangement of muscle fibers. Abbreviations: ex, exumbrella; go, gonads; $m$, mesoglea (ECM); ma, manubrium (feeding organ); $p$, plate endoderm (endodermal lamella in A1); rc, radial canal; sm, smooth muscle of the manubrium (dark green); st, striated muscle (red); $t$, tentacles; $v$, velum.

pearance of striation had to be an artefact. Krasinska performed a detailed histological study of good quality in her doctoral thesis and provided evidence for bilaterian-like banding patterns in the medusa striated muscles (Fig. 1A; Krasinska, 1914). Secondly, the subepidermal location of striated muscle in most Medusozoa was not revealed until the $20^{\text {th }}$ century (Krasinska, 1914; Schmidt, 1920; Chapman, 1968, 1999; Fig. 1B).

Hydromedusa development had already been described by Agassiz (1860), Schulze (1873), Hertwig and Hertwig (1878, 1880), Weissmann (1880), Hamann (1882) and Goette (1887, 1907). The descent of the striated muscle from a newly formed third layer, called entocodon, was not recognized as a mesodermal process but interpreted as an inward folding of the ectodermal layer of the polyp epidermis (Fig. 2A). Since the striated muscle also appeared to remain connected to the ectoderm, it was not attributed with an independent developmental identity. Thus the medusa structure was interpreted as a modified polyp "head" with an outgrowth of the hypostomal tissues between mouth and tentacles forming the medusa bell (reviewed in Korschelt and Heider, 1890; Fig. 2B). Electron microscopy finally supplied the necessary resolution to solve the issue, disclosing the complete separation of the entocodon from the ecto- and endoderm by a layer of ECM (Bölsterli, 1977). The entocodon thus forms a compartment of its own and merits mesodermal status (see below). As a consequence the diploblast status of the Hydrozoa became disputable and entocodon formation was related to the ontogeny of the mesoblastemal lining of the coelomic cavity of Sipunculida (Boero et al., 1998). The apparent restriction of entocodon formation and lateral medusa budding on the polyp, to the Hydrozoa, together with the paucity of experimental evidence for a mesodermal descent of the subepidermal striated muscle in Cubozoa and Scyphozoa, have promoted the view of the entocodon as hydrozoan specific tissue with minor resemblance to a mesoderm layer (Collins et al., 2006). Contrary to the bilaterian meso- 
derm-derived muscle with its three-dimensional organization in bundles the cnidarian muscles were regarded as epidermal folds forming two-dimensional sheets (Pantin, 1960; Chapman, 1966). Thus the cnidarian mesoderm-like anatomies were grouped within the diploblast state of the phylum and discussed as forerunners of the bilaterian mesoderm (Chapman, 1966).

Nevertheless, the diploblast classification of Cnidaria had already been challenged by the Hertwigs (Hertwig and Hertwig, 1878) who noted that Anthozoa have a mesenchymal mesodermal layer similar to that of the higher phyla. They had also located the striated muscle in a mesodermal position in some medusae and recognized the separation of the muscle from the covering epithelium by a lamella (Hertwig and Hertwig, 1880). Krasinska (1914) distinguished two types of medusa muscles, an epithelial and a subepidermal mesodermal muscle. This designation received full support by Hyman $(1940,1951)$ who regarded all triploblast-like anatomies in Cnidaria as of mesenchymal origin, which in her assessment amounted to a primitive way of mesoderm formation.

As discussed below three-dimensional mesoderm-like structures are not only present in the hydrozoan medusa entocodon but can also be found in anthozoan, cubozoan and scyphozoan polyps, in developmental and adult stages. Here they contribute to the formation of the ephyra or medusa subepidermal muscles. In the absence of entocodon formation mesoderm-like structures may be formed by transdifferentiation or by differentiation from mesenchymal cells.

\section{The cnidarian mesoderm unearthed}

\section{What is a mesoderm?}

In bilaterians, the mesoderm is "the germ layer that gives rise to the skeleto-muscular system, connective tissues, the blood and internal organs such as the kidney and the heart" (Wolpert, 1998). The first cell types arising in the ancestral mesoderm most likely were myocytes which gradually evolved into a muscle based locomotion system, located within the organism in a position suited for optimal biomechanical and physiological efficiency (reviewed in Rieger and Laduner, 2003; Seipel and Schmid, 2005). In the anatomies of most extant bilaterian phyla (except arthropoda) this muscle system is located between the outer epidermal and the inner digestive layers, where resilient structures like ECM, hydroskeleton or bone counteract the contraction force generated by the muscle. In the vertebrate limbs the muscles are located between the bones and the epidermis with a complete absence of endodermal layers indicating that the functionality of the muscle does not depend on a mesodermal position per se but on the agonist principle and on the corresponding anatomy. In theory, the muscle may even be placed in an ectodermal position. Of the large variety of cell types and organ systems produced by the bilaterian mesoderm only the ECM with its cellular components and the adhering muscle systems have functional analogs in the Cnidaria. These are the presumptive cnidarian mesodermal elements.

In all extant phyla mesoderm formation is correlated to gastrulation, a process starting with the inward movement of ectodermal cells and resulting in the formation of the endoderm and digestive tube. The literature distinguishes between ectomesoderm and

endomesoderm, indicating the descent of the presumptive mesoderm cells from the ectoderm or endoderm, respectively (reviewed in Hyman, 1951; Rieger and Laduner, 2003). Presumptive mesoderm cells, however, can be generated during the entire gastrulation process. Most endoderm cells are descended from cells originally located in an outer (epithelial) position. The time point of conversion from epithelial/ectodermal to endoderm lineage is not clearly defined. Conversion may take place early, when the cells start moving away from the surface, or late, when the primordial digestive tube has formed. The situation is even more confounded in the absence of a defined blastopore like in some Anthozoa or Phoronids where gastrulation occurs by a large
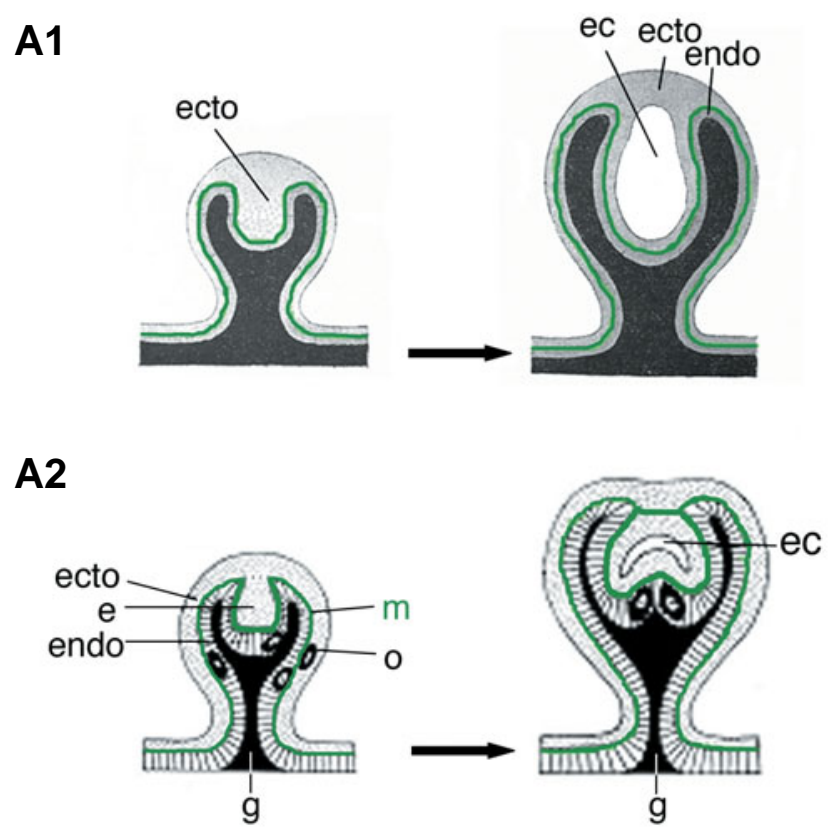

B

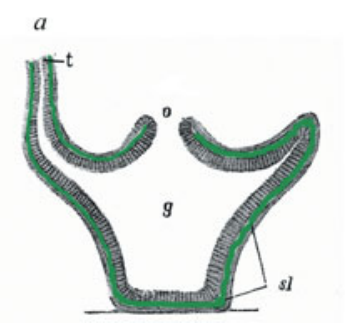

Fig. 2. Schematic presentations of medusa and polyp anatomies. (A) Entocodon formation in hydromedusae. (A1) after Korschelt and Heider (1890); (A2) after Bölsterli (1977) and Frey (1968). The entocodon forms by accumulation and invagination of ectodermal cells into the underlaying endoderm, followed by cavity formation (entocodon cavity) and differentiation of the subumbrellar muscle. While in (A1) the entocodal cells remain part of the ectoderm, in (A2) the entocodal cells are separated from the ecto- and endoderm by an ECM. Abbreviations: e, entocodon; ec, entocodal cavity; ecto, ectoderm; endo, endoderm; $m$, mesoglea (ECM). (B) Popular presentation of polyp (a) and medusa (b) suggesting an anatomical homology between the two life stages in favour of the polyp-medusa transformation hypothesis lafter Korschelt and Heider, 1890). Abbreviations: g, gastral cavity; gl, mesoglea between ecto- and endoderm; o, mouth opening; sl, polyp mesoglea; rik, ring canal; rk, radial canal; $v$, velum; $t$, tentacle. 
inward bend of the ectoderm layer or by multipolar delamination and immigration, a frequent pattern in cnidarian gastrulation. The large variations in the mode of mesoderm formation (reviewed in Hyman, 1951) indicate that the evolution of the different anatomies required a considerable developmental plasticity with a variety of pathways for the cells to locate their mesodermal positions. These aspects were well considered by Hyman (1951). She wrote "The term mesoderm is rather loosely applied to all cells, cell layers or cell masses which occur in the embryo between the ectoderm and the entoderm. The ectomesoderm of the Radiata and the Protostomia is undoubtedly the oldest form of mesoderm. It is always mesenchymaland consists of inwandered ectodermal cells. The entomesoderm (Deuterostomia), the true or definite mesoderm, includes all mesoderm arising from or with the entoderm. It may form as mesenchyme or as band, plate or sac, more or less epithelial in character... The time of origin of the entomesoderm is also variable." This definition has not been disputed by developmental biologists.

On these grounds it is difficult to understand the reasons for the current debate on the "true" mesoderm, especially as the histology on which most discussions are based, dates back to the $19^{\text {th }}$ and early $20^{\text {th }}$ century, a time when proper cell tracing was not feasible.

\section{Muscle cells in Cnidaria}

The ecto- and endodermal layers of cnidarian larvae and polyps consist of epithelial cells mostly with smooth muscle type filaments at their base (Fig. 3A). These epithelial muscle or myoepithelial cells are generally flagellated, of cuboidal appearance and have secretory, glandular or digestive activities. They are the first cell types to differentiate in the hydrozoan planula, shortly after the developing mesoglea separates the endo- and ectodermal cell layers (Gröger and Schmid, 2001). Myo-epithelial cells are viewed as characteristic and indicative of the ancestral position of the Cnidaria. Nevertheless flagellated myo-epithelial cells also occur as mesodermal derivatives in Bilateria such as Brachyopodes or Amphioxus (Storch and Welsch, 1974).

Apart from myo-epithelial cells other types of muscle cells have been described in Cnidaria. These muscle cells (Calgren, 1949) generally have a flattened, elongated morphology with large basal myofilaments of the smooth (Fig. 3B1) or striated
A

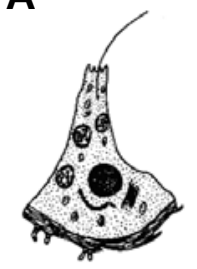

B1

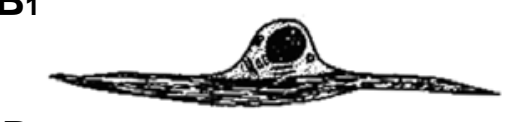

B2

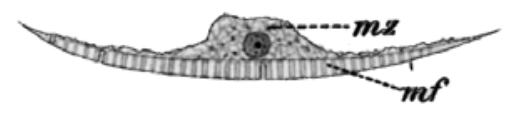

Fig. 3. Schematic drawings of the most common types of cnidarian muscle cells. (A) Myo-epithelial (epithelial muscle) cell, mostly flagellated and of cuboidal shape, sometimes with large basal extensions. It has secretory and glandular function and forms the ecto-and endodermal layers of larvae and polyps. In the medusa it is present in the manubrium and the tentacles. (B) Muscle cells. $\left.\mathbf{( B}_{\mathbf{1}}\right)$ Smooth muscle cell, occasionally flagellated, epidermal and/or subepidermal. $\left.\mathbf{( B}_{2}\right)$ Striated muscle cell, mostly subepidermal. After Doumenc (1979) and Krasinska (1914).
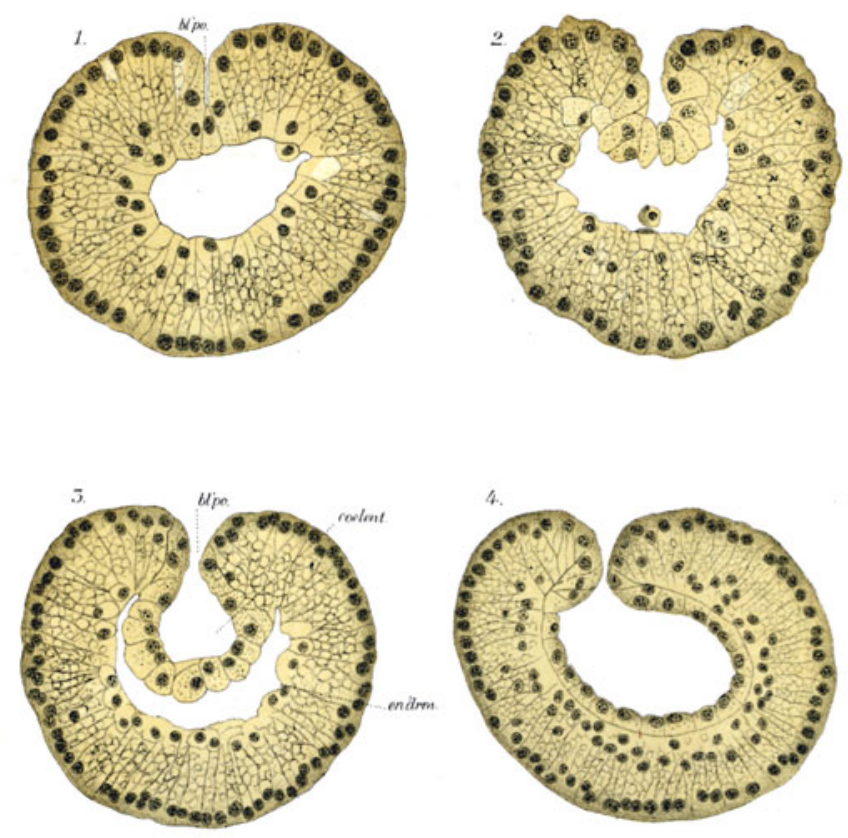

Fig. 4. Gastrulation in Aurelia flavidula (Smith, 1881). Drawings of sectioned embryos in chronological order (1-4). Before formation of the blastopore, cells from the surface move inward and form a cellular layer in proximity to the ECM of the developing endodermal layer. Abbreviations: blpo, blastopore; coelent, coelenteron; endrm, endodermal layer.

muscle varieties (Fig. 3B2). They can be epithelial or subepithelial forming two-dimensional sheets or three-dimensional bundles (see below). Compared to the myo-epithelial cells they differentiate later in development, often deeply embedded in the ECM, unconnected to the epithelial layers. Where the lineages have been investigated, the muscle cells originate by mesodermal process (see below). Interestingly, the medusa and bilaterian striated muscles have the same banding pattern (Krasinska, 1914; Bouillon etal., 1958; Chapman etal., 1962; Schuchert etal., 1993).

Histology and experimental data obtained from marine Hydrozoa (Braverman, 1974; Bölsterli, 1977; Acherman, 1980; Schmid, 1992; Bouillon, 1993; Van de Vyver, 1993) and Scyphozoa (Hujer and Lesh-Laurie, 1995), showed that both myo-epithelial and muscle cells readily transdifferentiate into each other but also into non-muscle cell types (neurons, nematocytes). They also have the ability to autonomously regenerate medusa organs in vitro (reviewed in Schmid, 1992). Thus, the cnidarian muscle cells can reactivate stem cell programs and exhibit a cellular plasticity unsurpassed in the animal kingdom. Furthermore, they constitute a cellular source not only for regeneration but also for the development of mesodermal structures like the entodocon in the hydrozoan polyp-medusa transition.

\section{Mesodermal muscle in Hydrozoa?}

The hydrozoan planula endoderm forms by delamination, polar or multipolar immigration, or ingression, but never by invagination (reviewed in Tardent, 1978). With genuine diploblast anatomies hydrozoan larvae and polyps do not feature cell types 
of mesodermal origin. The hydromedusa bell, however, is composed of three to four cell layers. One cell layer consisting of mononucleated, bilaterian-like striated muscle is located subepidermally in the subumbrella of most medusae (Fig. 1B) and in an epidermal position in some Antho-, Narco- and Trachymedusae (all Hydrozoa). In most Hydromedusae the striated muscle derives from the entocodon, a third three-dimensional cell layer which develops between the ecto- and endoderm (Fig. A2, reviewed in Seipel and Schmid, 2005). In transplantation experiments the entocodon acts autonomously as organizer for medusa development (Reisinger, 1957), thus reproducing the organizer abilities of bilaterian blastopore tissues observed in comparable transplantation experiments with amphibians. Further support for the mesoderm character of the entocodon was provided by the finding that cnidarian cognates to bilaterian mesodermal ( Twist, Spring et al., 2000; Brachyury, Spring et al., 2002) and myogenic genes (JellyD1, Id, Snail, Mef2, reviewed in Seipel and Schmid, 2005) are involved in the formation of the entocodon and its differentiation products, the striated and smooth muscles of the medusa bell. Interestingly, most of these genes are not expressed when the larval ectodermal myo-epithelial cells differentiate (Spring et al., 2000; 2002; Müller et al., 2003). Thus the analysis of developmental and cellular gene expression patterns indicates the existence of two distinct differentiation pathways, one for myo-epithelial cells, one restricted to muscle cells.

In contrast to the previous view of a "primitive" cnidarian mesenchymal mesoderm (Hyman, 1951) the hydromedusa entocodal mesoderm is non-mesenchymal, as it forms a separate coherent three-dimensional structure (mesothelial developmental compartment) which cavitates and then differentiates the subumbrellar muscle and nerve cells of the RFamide type (Seipel et al., 2004). Thus, in Hyman's terminology as well as in the more restrictive version requesting three-dimensionality as formulated by Pantin (1960) and Chapman (1966), the entocodon classifies as a true or definite mesoderm.

\section{Mesodermal differentiation in Scyphozoa, Cubozoa and Anthozoa?}

Scyphozoan planula development can take many routes covering a variety of invagination and unipolar ingression processes (Franc, 1993). The larvae exhibit the typical cnidarian diploblast histology. An unusual case of invagination has been reported for Aurelia flavidula where a third layer of cells is formed by multipolar delamination from the ectoderm shortly before and during the invagination process of the endodermal cells (Fig. 4, Smith, 1881). Similar but apparently less-documented observations have been presented for Mastigias papua (Uchida, 1926). The further developmental fate of these cells is not known; maybe they contribute to the formation of the mesogleal mesenchymal cells or degenerate in later development. Polyp formation follows settlement of the larva similar to the Hydrozoa. In general the anatomy of the scyphistoma (polyp) resembles the anthozoan polyp and in the Stauromedusa and Coronata (Stephanoscyphus) the scyphistoma display polyp and medusa characters (Werner, 1967). All scyphozoan polyps feature retractor muscles and many have amoebocytes embedded in the extracellular matrix. Both smooth muscle and striated myofibers have been reported in the tentacle base, the outer oral disc and the upper part of the retractor muscle in Aurelia aurita (Chia et al., 1984). The retractor muscles have been interpreted as a two-dimensional ectodermal lamella, aborally directed and growing inward from the peristom field, in which the muscle fibrils giving rise to the septal muscles differentiate (Goette, 1887; Hein, 1900; Hargitt and Hargitt, 1910; Chapman, 1966). In developing polyps of Cyanea palmstruchi, at very early scyphistoma stage (before tentacles have developed and when the calyx endoderm is only partly formed), three-dimensional strands of mesenterial muscle develop from ectodermal cells invading the ECM from the hypostom field, but also emanate from the ectoderm of the column as the mesenteries gradually grow towards the pedal disk (Fig. 5, Widersten, 1966). In the Stauromedusa Haliclystus octoradiatusthe retractor muscle similarly develops from proliferative cells migrating basally from the hypostomal teaniole ectoderm. The three-dimensional strands of smooth muscle become entirely embedded in the ECM and have no direct contact with the ectodermal or endodermal layers (Fig. 6 , Wietrzykowski, 1912). Some scyphistoma feature podocysts formed as three-dimensional nodules between the ecto- and endoderm by dedifferentiating ectodermal myo-epithelial cells invading the ECM and transdifferentiating to an unusual type of amoebocyte (Chapman, 1966). The Scyphozoa have well developed medusa stages with epidermal smooth and subepidermal striated muscle (Chapman etal., 1962; Chapman, 1968; 1999). In the tentacles of Pelagia, a scyphozoan species lacking the polyp stage, smooth muscle cells form tube-like bundles of nerve and muscle cells (Krasinska, 1914). These tubes are deeply embedded in the ECM and bilaterally organised mostly without connection to the ecto- or endodermal layers (Fig. 7). Ephyra and medusa development has not been studied in detail with respect to the origin of striated muscle but in the absence of entocodon forma-

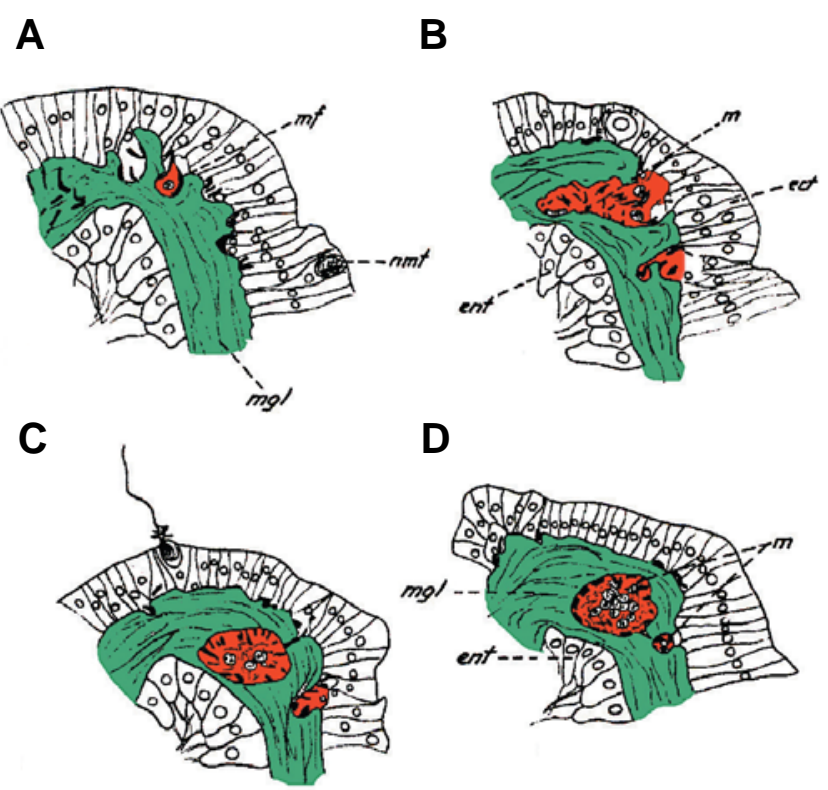

Fig. 5. Retractor muscle formation in Cyanea palmstruchi(Scyphozoa) after Widersten, 1966. Drawings of sections of the developing scyphistoma polyp in chronological order (A-D), magnification 385x. Cells immigrate from the ectoderm into the mesoglea to form the retractor muscle. Abbreviations: ent, endoderm; m, muscle (cytoplasm red, nuclei white); $\mathrm{mf}$, muscle filaments; mgl, mesoglea (green); nmt, nematocytes. 
tion their modes of development are certainly different from the Hydrozoa. As mesenchymal cells and mesodermal-like subepidermal muscle are already present in the polyp stage they participate in the formation of the mesodermal-like anatomies (subepithelial muscle) at the meduse stage by transdifferentiation of mesenchymal or muscle cells.

Cubozoan embryonic development has not been documented. In Tripedalia cystophora the larvae have single celled ocelli, but do not exhibit bilayered epithelial anatomy, nor defined muscle or nerve cells (Nordström et al., 2003). The polyps lack mesenteries and retractor muscles. They have no putative mesodermal elements apart from striated muscle-like cells in the ectodermal tip of the polyp tentacles (Chapman, 1978), which, however, apparently lack the typical banding pattern observed in medusa and bilaterian striated muscles (Chapman et al., 1962; Schuchert et al., 1993). The transformation of the polyp into a medusa leads to the formation of a bell structurally related to the hydromedusa bell. In the tentacles of Carybdea marsupialis the longitudinal smooth muscles are organized as tubes, completely separated from the epithelial muscles and embedded in a massive ECM (Claus, 1878), an anatomical trait also found in the scyphozoan medusa of Pelagia.

Anthozoan muscle differentiation appears to be restricted to two types of smooth muscle (Hyman, 1940; Amerongen and Peteya, 1980). Although Cnidaria were classified very early as diploblasts it had also been agreed that the Anthozoan polyp anatomy contained triploblast elements originating from a mesen-
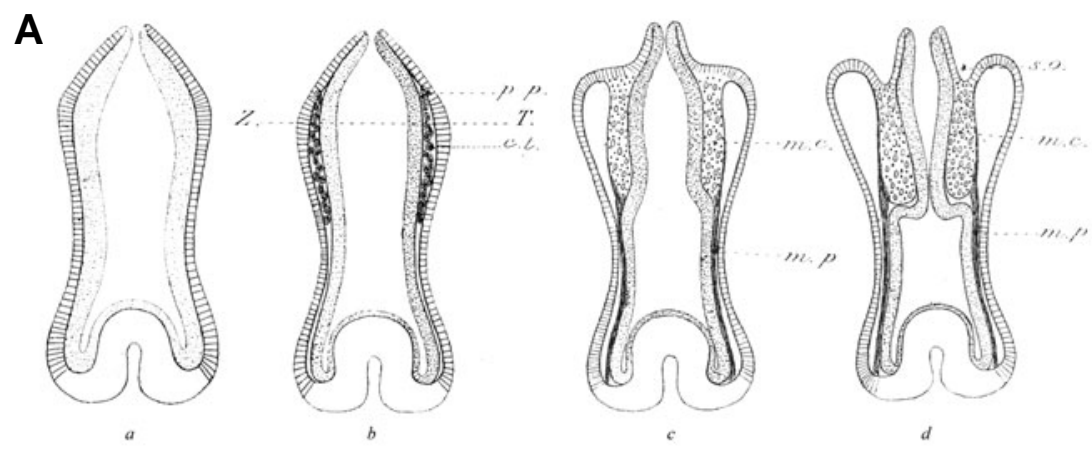

B

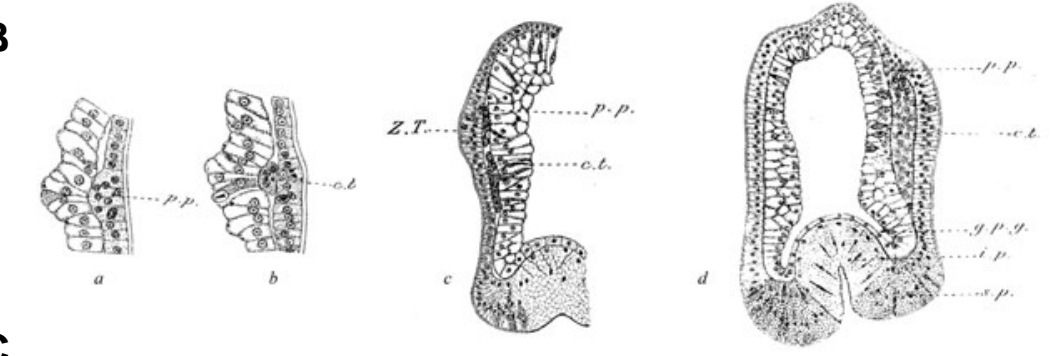

C

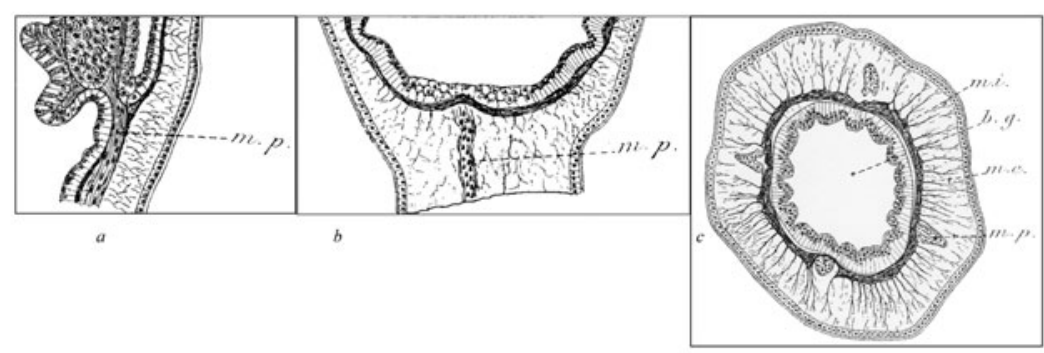

chymal ectomesoderm (Hertwig and Hertwig, 1879; 1882; Kovalevsky and Marion, 1883; Korschelt and Heider, 1890; Hyman, 1940; Chapman, 1966). Today Anthozoa are presented uniformly as diploblasts (Tardent, 1978; Pechenik, 2000; Barnes et al., 2001; Brusca and Brusca, 2003), without definite "real" muscle and with the retractors viewed as longitudinal processes from the myo-epithelial muscles (Martindale et al., 2004). There is, however, contradicting evidence, reviewed in the following paragraph.

During anthozoan larval development, the endoderm forms in octocorals by delamination (Tixier-Durivault, 1987), in hexacorals by invagination and multipolar ingression (Van-Praet and Doumenc, 1987). In the Actiniidae (hexacorals) the invagination is located at the posterior, oral pole of the embryo (blastopore) and can directly transform into a functional mouth (Tardent, 1978). Shortly after stomodeum formation and before settlement of the planula the mesenteries form as bilateral outgrowths from the endoderm layer at the oral/blastopore pole and gradually grow towards the anterior pole. Early during this process a collagenous matrix is synthesized by both epithelial layers (Doumenc, 1979). The retractor muscle, the amoebocytes, occasionally the scleroblasts and the gonads (reviewed in Hyman, 1940) differentiate in this ECM (Fig. 8A). The myofilaments of the retractor muscle are deeply anchored in the collagenous matrix and most of the muscle cells are clearly separated from the endodermal epithelial muscle (Fig. 8B; Doumenc, 1976, 1979). Conventional histology, ultrastructural and pulse-chase cell proliferation studies in Cereus pedunculatus (Actiniidae) indicate that all these cell types (except gametes?) appear to originate from ectodermal mesenchymous cells invading the matrix from the oral/gastrulation pole as the mesenteries differentiate (Doumenc, 1977; 1979). While some cells directly invade the developing matrix, others appear to migrate first along/in the endodermal layer of the developing mesenteries. Differentiation of the retractor myofilaments is initiated when the migrating cells loose contact to the endoderm, align along each other and build up the plume-like retractor muscle. This is very

Fig. 6. Development and anatomy of the retractor muscle in Haliclystus octoradiatus (Stauromedusa, Scyphozoa) after Wietrzykowski, 1912. (A) Schematic drawings of sagittal sections of the developing polyp (a-d) depicting growth of taeniole cellular mass, the upper hypostome part will differentiate nematocytes, the lower part forms the retractor muscle; (B) Formation of the taeniolar cordon by cells immigrating from the ectodermal epithelium, $(a, b)$ cross section of the subtentacular zone, 720x; $(c, d)$, sagittal section of the late developing polyp, 400x. (C) Detailed morphologies. (a) interface of muscle and nematocyte tissues in the taeniole, 220x; (b) tangential section of (a), 220x; c. cross section of lower pedal part with bundles of retractor smooth muscle deeply embedded in the outer mesoglea, 220x. Abbreviations: bg, basal gastrocoel; $c t$, taeniole cells; mc, columellar mass (nematocytes); me, outer mesoglea; mi, inner mesoglea; $m p$, retractor muscle; so, subumbrellar cavity; pp, proliferation zone. 

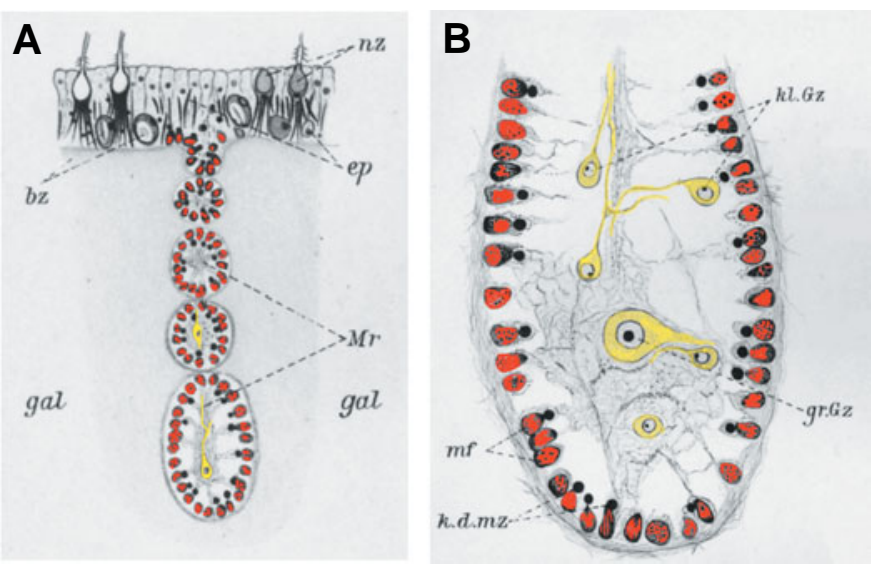

Fig. 7. Cross section through the tentacle of the scyphozoan medusa Pelagia noctiluca (after Krasinska, 1914). (A) Folds of the tentacle epithelium sink into the ECM and form tube-like bundles with smooth muscle cells (red) and accompanying nerve cells (yellow). (B) Magnified view of tubular structure in (A). Abbreviations: bz, nematoblasts; ep, tentacle epithelium; gal, mesoglea (ECM); gr.GZ, large nerve cells k.d.mz, nuclei of muscle cells; kl.Gz, small nerve cells; mf, myofilaments; Mr, tubes of muscle; nz, nematocytes.

similar to some annelida retractor muscles (Boulignard, 1966). The process starts at the oral pole and progresses as the mesentery grows towards the aboral end (Doumenc, 1979). There are also cells migrating into the budding tentacles, however, there they are incorporated into the ectodermal epithelium (Doumenc, 1979). Some elements of the nervous system also develop in a similar process. The situation is reminiscent of the hydrozoan entocodon, which has the ability to differentiate both muscle and nerve cells, indicating an evolutionary connection between the two cell types (Seipel et al., 2004). The formation of mesenchymal cells from ectodermal epithelial cells invading the ECM was also reported in the alcyonarian Sympodium (Fig. 8C; Kovalevsky and Marion, 1883). In summary the mesenterial retractor muscles in Scyphozoa and Anthozoa are of ectoblastemal origin and form bundles of smooth muscle in part or fully embedded in the ECM. Although a more detailed analysis is required, the available data indicate that polyps of both cnidarian classes have three-dimensional muscle anatomies of mesodermal/mesenchymal origin. Recent gene expression studies on mesodermal/ myogenic and patterning genes in the anthozoan Nematostella vectensis do not contradict this conclusion (Martindale et al., 2004).

\section{Urtriploblast: mesoderm and muscle as part of the basic triploblast Bauplan}

To integrate all the data we are confronted with two unique scenarios: 1) The cnidarian "mesoderm" and its two- or threedimensional muscle derivatives are homoplastic to the bilaterian mesoderm resulting from a convergent evolution, or 2) The cnidarian and the bilaterian mesoderms are homologous, implying the existence of a common triploblast ancestor.

In the first case, a common diploblast planuloid ancestor seems plausible and triploblasty may have evolved simply by addition of a third germ layer. The planuloid ancestor evolved a polypoid diploblast life form, possibly spearheaded within the
Cnidaria by the sessile Anthozoa, likely representing the oldest group within the Cnidaria (Collins et al., 2006). Development of the triploblast polyp and medusa anatomies may have occurred secondarily on co-option principles as discussed for other gene cascades (Revilla-i-Domingo and Davidson, 2003). However, as sessility, wherever present in extant phyla, is mostly accompanied by reductions in locomotive and neuronal anatomies, the "invention" of a mesodermate/triploblast development and the medusa by a sessile diploblast polypoid ancestor may be a less parsimonious scenario (for additional arguments see Seipel and Schmid, 2005).

In the second case, cnidarians and bilaterians share a common precambrian triploblast ancestor, with a basic Bauplan anatomy composed of an epidermal layer, a digestive and reproductive anatomy and a locomotive system based on muscle cells. This Urtriploblast ancestor corresponds to the closest ancestor of the Urbilateria (deRobertis and Sasai, 1996). Its anatomy may be comparable to the Vernanimalcula (Chen et al., 2004). The position of the muscles, mesodermally along the digestive tube, or circumferentially away from the digestive area, promoted the bilateral or radial anatomies, respectively (Seipel and Schmid, 2005). This common ancestor may have displayed direct or indirect development with lecitotrophic larvae, but no polyp stage. On the basis of this second hypothesis Cnidaria appear to be derived triploblasts with the diploblast hydrozoan polyp as secondary larval stage. This scenario confirms a hypothesis supported by many life cycle and anatomical studies of Hydrozoa (reviewed in Bouillon, 1993). Reductions or complete loss of the medusa stage occurred several times in the evolution of all the medusozoan classes, most notably in the Hydrozoa (Tardent, 1978; Govindarajan et al., 2006). With the medusa as the adult and the polyp as a post-planula, larval stage (Boero and Bouillon, 1987; Boero et al., 1992; Boero et al., 1998), medusa development may be the terminal phase of an embryonic development starting with planula formation, interrupted by the formation of a hydroid colony by asexual reproduction, to be continued with medusa budding (Boero et al., 2002).

\section{From triploblasty to diploblasty or from direct to indirect development}

\section{The establishment of the cnidarian life cycles}

Under the assumption that cnidarians derive from a triploblast ancestor diploblasty may be considered a theoretical construct or a historical reminiscence (Hyman, 1951; Willmer, 1990; Ball et al., 2004; Seipel and Schmid, 2005). Nevertheless the extant cnidarians display body parts and/or life cycle stages of purely diploblast character. With a descent from a common triploblast ancestor diploblast traits may have arisen concurrent to the later addition of larval stages (see above) and by cnidarian specific developments favouring epithelial structures.

In difference to the other marine invertebrates most Cnidarian species feature life cycles with sessile larval polyps and pelagic adult sexual medusae. The evolutionary factors favouring development of the life cycle stages have been discussed repeatedly (Edwards, 1973; Calder, 1990; Peterson, 1990 and reviewed in Boero, 1992; Boero et al., 2002) on the basis of environmental factors. The nematocyte may be considered the essential cellular element favouring larval sessility. Cnidaria generally catch prey 
A

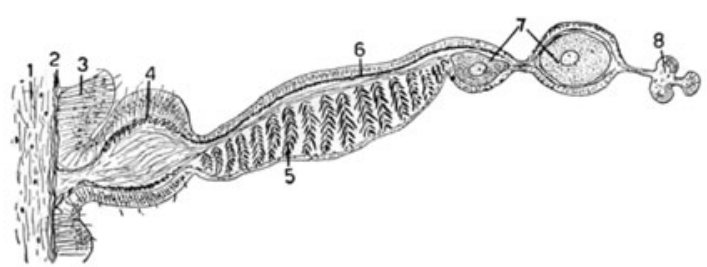

$\mathrm{A} 2$

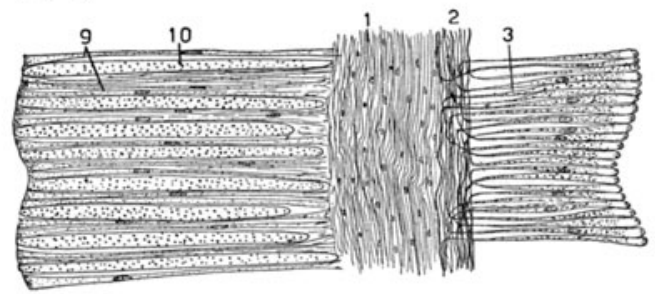

B1

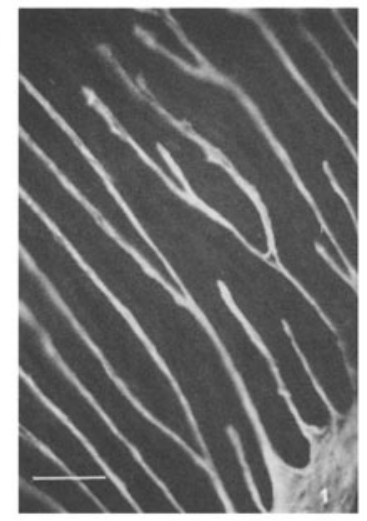

$\mathrm{B}_{2}$

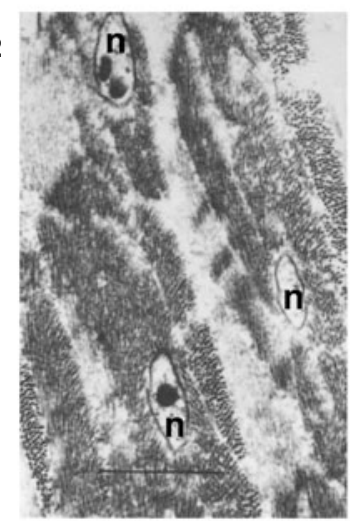

C

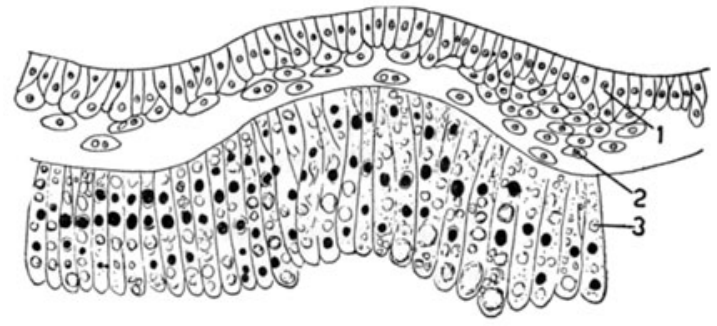

Fig. 8. Mesodermal anatomies in Anthozoa. A Drawing of cross section through a mesenterium (A1) and the body wall (A2) of an anemone (after Hyman, 1940). Captions: 1, mesoglea with mesenchyme cells; 2, circular muscle filaments of the endodermal myo-epithelial cells; 3, endoderm; 4, parietal muscle; 5, retractor muscle; 6, transverse mesenterial musculature; 7 , gonads; 8 , mesenterial filament; 9 , supporting cells of epidermis; 10, mucous cells of epidermis. B. Retractor muscle in the mesentery of Cereus pedunculatus (after Doumenc, 1979). B1. Myofilaments in the collagen matrix (collagen immunostaining). B2. Ultrastructure of the retractor muscle. Bar is $40 \mu \mathrm{m}$ in B1 and $1 \mu \mathrm{m}$ in B2. Abbreviations: $n$, nuclei. C. Formation of mesenchyme by inwandering of ectodermal cells in the ECM in the alcyonarian Sympodium lafter Kovalevsky and Marion, 1883). Captions: 1, ectoderm; 2, mesenchyme; 3 , endoderm.

by nematocyte discharge from the tentacles thereby omitting chase. The nematocytes differentiate very early in development from the endodermal layer (Van de Vyver, 1993; Gröger and Schmid, 2001), thus enabling a juvenile life stage to forage on the same substrate as the adult. This ability supported the evolution of the sessile polyp. The selective pressure for the differentiation of a mesodermal locomotive anatomy was low leading to a reduction or loss of the medusa stage in a variety of cnidarian species. Alternatively, the medusa may have become sessile and reduced their triploblast anatomy. This developmental plasticity is exemplified in scyphozoan polyps displaying medusa anatomies (Tardent, 1978) and in some hydrozoan medusae transforming back to the polyp stage, in a "reverse" development (Piraino et al., 2004; De Vito et al., 2005). Mesodermal traits were only maintained as part of the developmental program where functionally necessary, but neither in planulae nor in the small hydrozoan polyp stages, nor in the digestive tube and the tentacles of the small hydrozoan medusa, where myo-epithelial cell layers and mesogleal anatomies provide sufficient contraction for feeding and digestion.

The Narco- and Trachymedusae do not fit into this scheme. They develop directly, without a polyp stage. In evolutionary time they may never have evolved a polyp stage or reduced the polyp stage secondarily (Bouillon, 1993). Although a pair of somite-like structures between the ecto- and endoderm has been described in the larva of the Narcomedusa Solmundella (Dawydoff, 1907), histological data indicate a direct formation of the medusa striated muscle from the ectodermal epithelium (Metschnikoff, 1882, 1886; Bouillon, 1987). Apparently the myogenic differentiation programs can be activated in the epithelia layers, in an ectodermal position. The occasional epidermal position of both types of cnidarian muscle may represent a derived state. Similar anatomies have also been reported for Bilateria (e.g. entoproct tentacles, Nielsen and Rostgaard, 1976).

\section{Gastrulation and life cycle evolution}

If the common ancestor of cnidarians and bilaterians was a motile triploblast displaying a basic bauplan including a primitive mesoderm-like layer and a medusa-like anatomy, the polyp stage may be considered an intermediate life stage. Considering histology and development as well as the expression patterns of key regulatory genes the most likely developmental phase to insert a polyp stage may be during gastrulation (Spring et al., 2000, 2002; Müller et al., 2003), in the Hydrozoa this is immediately after the formation of the larval endoderm. Metamorphosis of the larva into the polyp does not require differentiation of new tissue layers or cell types and can proceed without DNA-replication (unpublished, Schmid). The differentiation of the polyp stage, however, does not always require sessility as exemplified by the Anthozoa, the hydrozoan Narcomedusa (Tardent, 1978) and the Leptomedusa Eirene hexanemalis (Bouillon, 1983). In the latter the floating hydroid forms the medusa bud and entocodon at the pedal, aboral end and, like Cubozoa, completely transforms into a medusa. In this case the polyp stage may be the result of a heterochronic process, with an abridged developmental program leading to the premature sexual maturation of the metamorphosed planula.

In the Scyphozoa polyp development includes migration of mesenchymal cells and formation of the three-dimensional subepidermal retractor muscle. This is followed by the transformation of the scyphistoma polyp into the ephyra and medusa stage. In the absence of histological and experimental data it can be speculated that the mesodermal elements present in the polyp anatomy may be recruited by transdifferentiation to form the sub-epidermal striated muscle of the medusa. Biphasic mesoderm development 
also occurs in the Echinoderms, with formation of the larval skeleton by mesenchymal micromeres and of the adult coelom sacs during metamorphosis.

Phylogenetic studies based on mitochondrial DNA structure, ribosomal RNA sequence and cladistic analysis position the Anthozoa at the base of Cnidaria (reviewed in Ball et al., 2004; Collins et al., 2006). From this it had been inferred that all the other cnidarian classes had evolved further away from the ancestral anatomy and life cycles than the anthozoans. In contrast to the other cnidarian classes, the anthozoans differentiate mesodermal elements early in development, during the larval-polyp transition and before the polyp becomes sedentary. In terms of anthozoan evolution there are two scenarios: 1) Similar to the other classes, the ancestral medusoid anatomy has been reduced, although to a lesser extent, in the anthozoan ancestor, when it became sessile. 2) Since anthozoans do not form medusae, their mesodermal elements may originate from a mesodermate ancestor distinct from the ancestor of the other medusozoan classes (see Seipel and Schmid, 2005).

\section{Conclusions}

The data analyzed in this review indicate that Cnidaria differentiate both diploblast and triploblast anatomies, the latter derived in a mesodermal process as defined by Hyman (1940, 1951), Pantin (1960), Chapman (1966) or Nielsen (1995). This is supported by molecular developmental studies of the hydrozoan entocodon and its differentiation product, the subumbrellar medusa muscle (Seipel and Schmid, 2005). Together, the cnidarian mesodermal anatomies and the conserved regulatory gene cascades point to a common triploblast ancestor of Cnidaria and Bilateria, the Urtriploblast. Under the assumption that developmental sessility correlates with reduced anatomical complexity we propose the Urtriploblast as a mobile organism, maybe of medusa-like anatomy, with direct or indirect development, but lacking a sessile life cycle stage.

\section{Summary}

The cellular and developmental analysis of evolutionary-conserved genes directing bilaterian mesodermal and myogenic cell fate previously identified the hydromedusan entocodon and its differentiation product, the striated muscle, as mesodermal derivatives. In view of these findings we presented a hypothesis disputing the diploblast classification of cnidarians without providing further explanations for the apparent diploblasty of the polyp stage and the formation of the subepidermal striated muscle in those Medusozoa lacking the entocodon nodule (Seipel and Schmid, 2005).

Hence we carried out a systematic review of the histological and experimental evidence for mesodermal differentiations in cnidarians. In anthozoan and scyphozoan but not in hydrozoan polyps the presumptive mesodermal elements include amoeboid cells, the mesentery retractor muscles and scleroblasts, all of which are embedded or deeply rooted in the extracellular matrix (mesoglea) and derive from the ectoblastemal cells invading the extracellular matrix from the gastrulation site during or shortly after endoderm formation. These data lend further support to the cnidarian mesodermate hypothesis, whereby cnidarians and bilaterians share a common triploblast ancestor, the Urtriploblast, a small, motile, possibly medusa-like organism that did not feature a sessile polyp stage in its life cycle. As a consequence the diploblasty of the hydrozoan polyps may represent a derived morphology resulting from heterochronic modulations of the gastrulation process after endoderm formation.

\section{Acknowledgments}

We thank Dr. B. Galliot (Geneva) and the reviewers for their helpful comments.

\section{References}

ACHERMANN, J. (1980). The fate and regeneration capacity of isolated ecto- and endoderm in polyps of Podocoryne carnea M. Sars (Hydrozoa, Athecata). In: Developmental and Cellular Biology of Coelenterates (ed. P. and R. Tardent), Elsevier Biomedical Press, p. 273-279.

AGASSIZ, L. (1860). Contributions to the Natural History of the United States of America. Boston. Truber and Co. Vol. 3.

ALLMAN, G. (1853). On the Anatomy and Physiology of Cordylophora. Phil. Trans London.

AMERONGEN, H.M. and PETEYA, D.J. (1980). Ultrastructural study of two kinds of muscle in sea anemones. The existence of fast and slow muscles. J. Morph 166: $145-154$

BAER, K.E. von. (1835). Blicke auf die Entwicklung der Wissenschaft. Petersburg

BALL, E.E., HAYWARD, D.C., SAINT, R. and MILLER, D.J. (2004). A simple plan - Cnidarians and the origin of developmental mechanisms. Nat. Rev. Genet. 5: 567-577.

BARNES, R.S.K., CALOW, P., OLIVE, P.J.W., GOLDING, D.W. and SPICER, J. (2001). The Invertebrates. A Synthesis. Oxford, UK. Blackwell Science.

BOELSTERLI, U. (1977). An electron microscopic study of early developmental stages, myogenesis, oogenesis and cnidogenesis in the Anthomedusa Podocoryne carnea M. Sars. J. Morph. 154: 259-289.

BOERO, F., BOUILLON, J. and PIRAINO, S. (1992). On the origin and evolution of hydromedusan life cycles (Cnidaria, Hydrozoa). Sex origin and evolution. R. Dallas (ed). Selected Symposia and Monographs U.Z.I., 6. Mucchi, Modena, 59-68.

BOERO, F. and BOUILLON, J. (1987). Inconsistent evolution and paedomorphosis among the hydroids and medusae of the Athecatae/Anthomedusae and the Thecatae/ Leptomedusae (Cnidaria, Hydrozoa). In: J. Bouillon, F. Boero, F. Cigogna and P.F.S. Cornelius (eds.), Modern trends in systematics, ecology and evolution of hydroids and hydromedusae, p. 229-250. Clarendon Press, Oxford.

BOERO, F., GRAVILI, C., PAGLIARI, P., PIRAINO, S., BOUILLON, F. and SCHMID V. (1998). The cnidarian premises of metazoan evolution: from triploblasty, to coelom formation, to metamery. Ital. J. Zool. 65: 5-6.

BOERO, F., BOUILLON, J., PIRAINO, S. and SCHMID, V. (2002). Asexual reproduction in the Hydrozoa (Cnidaria). In: Reproductive Biology of Invertebrates, Vol. XI (R.N. Hughes, ed), p. 141-158, Oxford \& IBH Publishing C. PVT. LTD. New Delhi, Kolkata.

BOUILLON, J., CASTIAUX, P. and VANDERMEERSSCHE, G. (1958). Musculature de la Méduse Limnocnida Tanganyicae (Hydroméduse). Extrait du Bulletin de Microscopie appliquée (2) t. 8, n 4, aout, p. 81-87.

BOUILLON, J. (1983). Sur le cycle biologique de Eirene hexanemalis (Goette, 1886), (Eirenidae, Leptomedusae, Hydrozoa, Cnidaria). Cahier de Biologie Marin, Tome XXIV, p. 421-427

BOUILLON, J. (1987). Considération sur le dévelopment des Narcoméduses et sur leur position phylogénétique. Indo-Malayan Zool. 4: 189-278.

BOUILLON, J. (1993). Classe des hydrozoaires. In Grassé, P.-P. (Ed.), Traité de Zoologie. Cnidaires, Ctenaires, Vol. III, Fascicule 2. Masson, Paris, p. 29-416.

BOULIGNARD, Y. (1966). La disposition des myofilaments chez une annélide polychète. J. Microsc. 5: 305-322.

BRAVERMAN, M. (1974). The cellular basis for colony form in Podocoryne carnea. Am. Zool. 14: 673-698. 
BRUSCA, R.C. and BRUSCA, G. J. (2003). Invertebrates. Sinauer Ass., Sunderland, MA.

CALDER, D. (1990). Seasonal cycles of activity and inactivity in some hydroids from Virginia and South Carolina, USA. Can. J. Zool. 68: 442-450.

CALGREN O. (1949). A survey of the Ptychodactiaria, Corallomorpharia and Actinaria. K.V.A. Handl. 1: 1-121.

CHAPMAN, D.M., PANTIN, C.F.A. and ROBSON, E.A. (1962). Muscle in Coelenterates. Rev. Canad. Biol. 21: 267-278.

CHAPMAN, D.M. (1966). Evolution of the scyphistoma. Symp. Zool. Soc. Lond. 16: 51-75.

CHAPMAN, D.M. (1968). A new type of muscle cell from the subumbrella of Obelia. J. Mar. Biol. Assoc. UK. 48: 667-688.

CHAPMAN, D.M. (1978). Microanatomy of the cubopolyp, Tripedalia cystophora (class Cubozoa). Helg. Wiss. Meeresunters. 31: 128-168.

CHAPMAN, D.M. (1999). Microanatomy of the bell rim of Aurelia aurita (Cnidaria: Scyphozoa). Can. J. Zool. 77: 34-46.

CHAPMAN, D., PANTIN, C.F.A. and ROBSON, E. (1962). Muscle in Coelenterates. Rev. Canad. Biol. 21: 267-278.

CHEN, J.Y., BOTTJER, D.J., OLIVERI, P., DORNBOS, S.Q., GAO, F., RUFFINS, S., CHI, H., LI, C.W., DAVIDSON, E.D. (2004). Small bilaterian fossils from 40 to 55 million years before the Cambrian. Science 305: 218-222.

CHIA, F.S., AMERONGEN, H.M. and PETEYA, D. (1984). Ultrastructure of the neuromuscular system of the polyp of Aurelia aurita L.1758 (Cnidaria, Scyphozoa). J. Morph. 180: 69-79.

CLAUS, C. (1878). Ueber Charybdea marsupialis. Arb. aus d. Zool. Inst. zu Wien. Bd. I.

COLLINS, A.C., SCHUCHERT, P., MARQUES, A.C., JANKOWSKY, T., MEDINA, M. AND SCHIERWATER, B. (2006). Medusozoan phylogeny and character evolution clarified by new large and small subunit rDNA data and an assessment of the utility of phylogenetic mixture models. Syst. Biol. 55: 97-115.

DAWYDOFF, C. (1907). Sur la question du mésoderme chez les Coelenterés. Zool. Anz. 31: 119-124.

DE ROBERTIS, E. M. and SASAI, Y. (1996). A common plan for dorsoventral patterning in Bilateria. Nature 380: 37-40.

DE VITO, D., PIRAINO, S., SCHMIECH, J., BOUILLON, J. and BOERO, F. (2006). Evidence of reverse development in Leptomedusae (Cindaria, Hydrozoa): the case of Laodicea undulata (Forbes and Goodsir 1851). Marin. Biol. in press.

DOUMENC, A.D. (1976). Etudes ultrastructurale des stades parenchymula, actinella et edwardsia de l'Actinie Cereus pedunculatus Pennant. Arch. Zool. Exp. Gén. 117: $2985 \mathrm{ff}$.

DOUMENC, A.D. (1977). Etudes dynamique de la morphogenèse au cours des phases actinella et edwardsia de l'actinie Cereus pedunculatus Pennant. Arch. Zool. Exp. Gén. 118: 79-102.

DOUMENC, A.D. (1979). Structure et origine des systèmes squelettiques et neuromusculaires au cours de l'organogenèses des stades postlarvaires de l'actinie Cereus pedunculaturs. Arch. Zool. Exp. Gén. 120: 431-476.

DOUMENC, A.D. and VAN PRAET, M. (1987). Ordre des Actinaires, Ordre des Ptychodactinaires, Ordre des Corallimorphaires. In Grassé, P.-P. (Ed.), Traité de Zoologie. Cnidaires, Anthozoaires, Vol. III, Fascicule 3. Masson, Paris, pp. 257-764.

EDWARDS, C. (1973). Contributary thoughts on form, function, habitat and classification in hydroids and hydromedusae. Publ. Seto Mar. Biol. Lab. 20: 11-22.

EIMER, T. (1878). Die Medusen physiologisch und morphologisch auf ihr Nervensystem untersucht. Tübingen.

FRANC, A. (1993). Classe des Scyphozoaires. In Grassé, P.-P. (Ed.), Traité de Zoologie. Cnidaires, Ctenaires, Vol. III, Fascicule 2. Masson, Paris, p. 597-884.

FREY, J. (1968). Die Entwicklungsleistungen der Medusenknospen und Medusen von Podocoryne carnea M. Sars nach Isolation und Dissoziation. Wilhelm Roux's Arch. 160: 428-464.

GOETTE, A. (1887). Entwicklungsgeschichte der Aurelia aurita und Cotylorhiza tuberculata. Leipzig.

GOETTE, A. (1907). Vergleichende Entwicklungsgeschichte der Geschlechtsindividuen der Hydroidpolypen. Z. wiss. Zool. 87: 1- 331.

GOVINDARAJAN, A.F., BOERO, F. and HALANYCH, K.M. (2006). Phylogenetic analysis with multiple markers indicates repeated loss of the adult medusa stage in Campanulariidae (Hydrozoa, Cnidaria). Mol. Phyl. Evol. 38: 820-834.

GROEGER, H. and SCHMID, V. (2001). Larval development in Cnidaria: a connection to Bilateria. Genesis 29: 110-114.

HAECKEL, E. (1874). Die Gastrea-Theorie, die phylogentische Klassification des Tierreichs und die Homologie der Keimblätter. Jena Z. Naturw. 8: 1-55.

HAMANN, O. (1882). Der Organismus der Hydroidpolypen. Jena. Z. Naturw. 15: 172.

HARGITT, C.W. and HARGITT, G.T. (1910). Studies on the development of Sycphomedusae. J. Morph. 21: 217-262.

HEIN, W. (1900). Untersuchungen über die Entwicklung von Aurelia aurita. Z. Wiss. Zool. 67: 1-40.

HERTWIG, R. (1882). Die Aktinien der Challengerexpedition. Jena.

HERTWIG, O. and HERTWIG, R. (1878). Der Organismus der Medusen und seine Stellung zur Keimblättertheorie. Jena.

HERTWIG, O. and HERTWIG, R. (1879). Die Aktinien. Jena Z. Naturw. 13.

HERTWIG, O. and HERTWIG, R. (1880). Der Organismus der Medusen und seine Stellung zur Keimblättertheorie. Leipzig.

HUJER, A. and LESH-LAURIE, G.E. (1995). Effect of mono-and divalent cations on polyp morphogenesis in isolated tentacles of Aurelia aurita (Scyphozoa). Dev. Gen. Evol. 205: 122-127.

HUXLEY, T.H. (1849). On the anatomy and the affinities of the family of the medusae. Phil. Trans. R. Soc. 2: 413-434.

HYMAN, L.H. (1940). The invertebrates: Protozoa through Ctenophora (Vol. I). McGraw-Hill, New York.

HYMAN, L.H. (1951). The invertebrates: Platyhelminthes and Rhyncocoela (Vol. II). McGraw-Hill Book Co, New York.

JICKELI, C.F. (1882). Ueber den histologischen Bau von Eudendrium Ehrbg. und Hydra L.C. Gegenbauer's Morph. Jahrb. 8: 373-416.

KRASINSKA, S.V. (1914). Beiträge zur Histologie der Medusen. Inaugural-Dissertation, Universität Zürich, Wilhelm Engelmann, Leipzig und Berlin.

KORSCHELT, K. and HEIDER, K. (1890). Lehrbuch der vergleichenden Entwicklungs-geschichte der wirbellosen Tiere. Jena. Gustav Fischer.

KOVALEVSKY, A. (1871). Embryologische Studien an Würmern und Arthropoden. Mém. Acad. St. Petersburg. 7. Ser. Tom. 16.

KOVALEVSKY, A. et MARION, A.F. (1883). Documents pour I'histoire embryogénetique des Alcyonaires. Ann. Mus. Hist. Nat. Marseille. Vol. 1. Pt. 2.

LANKESTER, R. (1877). Embryology and Classification. Quart. J. Micros. Sci. 1: 22-44.

LENDENFELD, R. (1888). Ueber Coelenteraten der Südsee. VII. Die Australischen Rhicostomeen. Z. wiss. Zool. 47.

MARTINDALE, M.Q., PANG, K. AND FINNERTY, J.R. (2004). Investigating the origins of triploblasty: "mesodermal" gene expression in a diploblastic animal, the sea anemone Nematostella vectensis (phylum, Cnidaria, class Anthozoa). Development 131: 2463-2475.

METSCHNIKOFF, E. (1882). Vergleichende Embryologische Studien. Z. Wiss. Zool. 36.

METSCHNIKOFF, E. (1886). Emybrologische Studien an Medusen. Ein Beitrag zur Genealogie der Primitivorgane. Wien.

MUELLER, P., SEIPEL, K., YANZE, N., REBER-MUELLER, S., STREITWOLFENGEL, R., STIERWALD, M., SPRING, J. and SCHMID, V. (2003). Evolutionary aspects of developmentally regulated helix-loop-helix transcription factors in jellyfish. Dev. Biol. 255: 216-229.

NASSE, O. (1882). Zur Anatomie und Pyhsiologie der quergestreiften Muskelsubstanz. Leipzig, F.C.W. Vogel.

NIELSEN, C. (1995). Animal Evolution: Interpretationships of the Living Phyla. Oxford Univ. Press.

NIELSEN, C. and ROSTGAARD, J. (1976). Structure and function of entoproct tentacles with a discussion of ciliary feeding types. Ophelia 15: 115-140.

NORDSTROEM, K., WALLÉN, R., SEYMOUR, J. and NILSON, D. (2003). A simple visual system without neurons in jellyfish larvae. Proc. R. Soc. Lond. 270: 23492354.

PANTIN, C.F.A. (1960). Diploblast animals. Proc. Linn. Soc. Lond. 171: 1-14. 
PECHENIK, J.A, (2000). Biology of the invertebrates. New York: McGraw-Hill Higher Education.

PETERSEN, K. (1990). Evolution and taxanomy in capitate hydroids and medusae. Zool. J. Linn. Soc. 100: 101-231.

PIRAINO, S., DE VITO, D., SCHMIECH, J., BOUILLON, J. and BOERO, F. (2004). Reverse development in Cnidaria. Can. J. Zool. 82: 1748-1754.

REISINGER, E. (1957). Zur Entwicklungsgeschichte und Entwicklungsmechanik von Craspedacusta (Hydrozoa, Limnotrachylina). Z. Morph. Oekol. Tiere 45: 656-698.

REVILLA-I-DOMINGO, R. and DAVIDSON, E.H. (2003). Developmental gene network analysis. Int. J. Dev. Biol. 47: 695-704.

RIEGER, R. and LADURNER, P. (2001). Searching for the stem species of Bilateria. Belg. J. Zool. 131: 27-34

SCHMID, V. (1992). Transdifferentiation in medusae. Int. Rev. Cytol. 142: 213-216.

SCHMIDT, W.J. (1920). Mehrfaserige (polyine) subepitheliale Muskelzellen bei Hydromedusen (Carmarina). Arch. Mikr. Anat. 93: $456 \mathrm{ff.}$

SCHNEIDER, K.C. (1893). Einige histologische Befunde an Coelenteraten. Jena Z. Naturw. 27.

SCHUCHERT, P., REBER-MUELLER, S. and SCHMID, V. (1993). Life stage specific expression of a myosin heavy chain in the hydrozoan Podocoryne carnea. Diff. 54: 11-18.

SCHULZE, F.E. (1873). Ueber den Bau von Syncoryne sarsiund der zugehörigen Meduse Sarsia tubulosa.

SEIPEL, K., YANZE, N. and SCHMID, V. (2004). Developmental and evolutionary aspects of the basic helix-loop-helix transcription factors Atonal-like 1 and Acheate-scute homolog 2 in jellyfish. Dev. Biol. 269: 331-345.

SEIPEL, K. and SCHMID, V. (2005). Evolution of striated muscle: jellyfish and the origin of triploblasty. Dev. Biol. 282: 14-26.

SMITH, F. (1881). The gastrulation of Aurelia flavidula, Pér. \& Les. Bull. Mus. Comp. Zool. Harvard Col. 22: 115-136.

SPRING, J., YANZE, N., MIDDEL, A.M., STIERWALD, M., GROEGER, H. and SCHMID, V. (2000). Ancestral role of the mesoderm specification factor twist in the life cycle of jellyfish. Dev. Biol. 228: 363-375.

SPRING, J., YANZE, N., JOESCH, C., MIDDEL, A.M., WINNINGER, B. and SCHMID, V. (2002). Conservation of Brachyury, Mef2 and Snail in the myogenic lineage of jellyfish: a connection to the mesoderm of Bilateria. Dev. Biol. 244: 372-384.

STORCH, V. and WELSCH, U. (1974). Epithelialmuscular cells in Lingula unguis
(Brachyopoda) and Branchiostoma lanceolatum(Acrania). Cell Tiss. Res. 154: 543-545.

UCHIDA, M. (1926). Anatomy and development of Mastigias. Tokyo Univ. Fac. Sci. Jour. Sect. 4, Zool. 1.

TARDENT, P. (1978). Coelenterata, Cnidaria. In Seidel, F. (Ed), Morphogenese der Tiere. Gustav Fischer Verlag, Jena, p. 83-289.

TECHNAU, U., SCHOLZ, C.B. (2003). Origin and evolution of endoderm and mesoderm. Int. J. Dev. Biol. 47: 531-539.

TIXIER-DURIVAULT, A. (1987). Sous-classe des Octocorallaires. In Grassé, P.-P. (Ed.), Traité de Zoologie. Cnidaires, Anthozoaires, Vol. III, Fas. 3. Masson, Paris, p. 3-188.

VAN DE VYVER, G. (1993). Reproduction sexuée-embryologie. In Grassé, P.-P (Ed.), Traité de Zoologie. Cnidaires, Ctenaires, Vol. III, Fas. 2. Masson, Paris, p. 417-471.

VAN PRAET, M., DOUMENC, D. (1987). Ordre des Antipathaires. In Grassé, P.-P. (Ed.), Traité de Zoologie. Cnidaires, Anthozoaires, Vol. III, Fas. 3. Masson, Paris, p. 189-256.

WEISSMANN, A. (1880). Zur Frage nach dem Ursprung der Geschlechtszellen bei den Hydroiden. Ueber den Ursprung der Gechlechtszellen bei den Hydroiden. Zool. Anzeiger.

WERNER, B. (1967). Morphologie, Systematik und Lebendsgeschichte von Stephanoscyphus (Scyphozoa, Coronata) sowie seiner Bedeutung für die Evolution der Sycphozoa. Zool. Anz. 30: 297-319.

WIDERSTEN, B. (1966). On the development of septal muscles, supporting fibrils and periderm in the scyphistoma of semaeostome Sycphozoa. Arkiv Zool. 18: 567-575.

WIETRZYKOWSKI, W. (1912). Recherche sur le development des Lucernaires. Arch. Zool. Expérimentale et générale. 5ième série, X, 1-95, pl. I à III.

WILLMER, P. (1990). Invertebrate relationships: Patterns in Animal Evolution. Cambridge Univ. Press, Cambridge, UK.

WOLPERT, L. (1998). Principles of Development. Oxford University Press, Current Biology LTD, London.

Received: January 2006 Reviewed by Referees: March 2006 Modified by Authors and Accepted for Publication: May 2006 Published Online: August 2006 